\title{
Synthesis of Some Heterocyclic Compounds Derived from Furfural Using Ultrasonic Waves
}

\author{
IM Shaban ${ }^{1}$ and Mohammad S Al-Ajely*2 \\ ${ }^{1}$ Basic science Department, College of agriculture, Northern Technical University, Iraq \\ ${ }^{2}$ Department of Chemistry, College of Education for women, Mosul University, Iraq
}

*Corresponding author: Mohammad S Al-Ajely, Chemistry Department, College of Education, Mosul University, Iraq

\section{ARTICLE INFO}

Received: 幽 September 28, 2019

Published: 幽 October 15, 2019

Citation: IM Shaban, Mohammad S Al-Ajely. Synthesis of Some Heterocyclic Compounds Derived from Furfural Using Ultrasonic Waves. Biomed J Sci \& Tech Res 22(1)-2019. BJSTR. MS.ID.003684.

Keywords: Heterocyclic compounds; Furfural; Ultrasonic waves

\begin{abstract}
Heterocyclic compounds especially those with Oxygen and Nitrogen atoms have shown many applications in chemotherapy as anti-cancer drug, anti-depression, anti-viral, anti-microbial as well as many other medical applications. In our investigation we use ultrasonic technique for preparing heterocyclic compounds mainly compounds $\mathrm{E}_{4}$, $\mathrm{E}_{5-7}, \mathrm{E}_{8-14}, \mathrm{E}_{15-18}$ and $\mathrm{E}_{19-22}$. Compounds $\mathrm{E}_{4}$ was prepared by condensation of meta toluidine with diabromo acrylyl chloride and cyclization with thiouria while compounds $\mathrm{E}_{5-7}$ were derived from either furfural as dibromo furfural on condensation with dimedon , compounds $\mathrm{E}_{8-14}$ were synthesized by condensation of dibromo furfural with acetone, urea , thiouria and sulfuric acid while compounds $\mathrm{E}_{15-18}$ and $\mathrm{E}_{19-22}$ were prepared from condensation of, $\alpha, \beta$ - Naphthol and urea using zarconyl chloride. The synthesized compound were identified by IR, NMR and were discussed.
\end{abstract}

\section{Introduction}

Furfural was first time produced industrially from rice huks in1840 after drying mixing with sodium chloride and addition of $10 \% \mathrm{H}_{2} \mathrm{SO}_{4}$ and distilled water [1], Other researchers have synthesized it from rice straw in 2007 [2]. Punsuvon and his coworkers have synthesized furfural from sugar cane stalks and sulfuric acid [3] with an overall yield of 71\%. In 2010 researchers have succeeded to synthesize furfural from xylose sugar [4]. In 2012 other researchers have prepared furfural from epic rap of wild mango [5]. In 2016 researchers have prepared furfural from bagasse [6] According to the above works it was known that furfural is cheap precursor and was used for the synthesis of variety of heterocyclic compounds. Furfural itself and its derivatives MCA, MBA for example 4,5-Dibromofurfuraldehydle, 2-(2-furyl) [1,3] dioxane,5nito(1,3-imidazolyl-2,5-dion)-3-yl furfuraldine was used as drag in treatment of urinary tract $[7,8]$. Among the reactions of furfural are the synthesis of tetrazine derivatives [9], furyl methylene diacetate [10] and 4-methyl furfural [11]. Among the known reactions of furfural which leads to the formation of heterocyclic compounds are the synthesis of 1,3-imidizolyl-2,5- furfuryl amine-2,s5- dione which is used for treatment of urinary tract infections [12]. Furoin compound on oxidation forms furil which is known as insect side [13]. flavon compound contains furfural ring, furfuraldehyde exhibited ICso values of 75.9,51.0 and 59.3 M for HT29, MCF7 and A498 respectively as anti-cancer cell lines [14]. It was also known that bromo derivative of furfural (MBA) reacts with boronyl indole to form indolyl derivatives of furfural, which is known for treatment of prostate, stomach, pancreatic, kolon cancer types [15]. In our investigation, We started from furfural as precursor for the synthesis of some heterocyclic compounds in continuing of our previous study [16-18] for the preparing of new derivatives of this type of furyl compounds in drug discovery program.

\section{Experimental}

All melting points were uncorrected and measured using Electro thermal melting point apparatus, All chemical were supplied by Aldrich and fluka and BDH companies. Bruker Avance $111400 \mathrm{MHz}$ was used for 1HNMR measurements. Infrared spectrophotometer model FT (600) CO. LTD (UK) and FT (8400 s) shimadzo were used for IR measurements. power sonic 405 micro process-controlled bench -top ultra-sonic cleaner was used for Ultrasound chemical 
condensation. Dibromo acrylic acid and its chloride derivative $\mathrm{E}_{1}, \mathrm{E}_{2}$ were prepared according to the published procedure [19]. Dibromo furfural and mucobromic acid were prepared following the published procedure $[20,21]$.

\section{Synthesis of 2-Bromo -N- (3-ethyl phenyl)-3, 3-dimethyl propion amide $\left(\mathrm{E}_{3}\right)$}

A mixture of $1.87 \mathrm{~g}$. of $\mathrm{KHCO}_{3}$ in $10 \mathrm{ml}$ of water was mixed with (1.18 g., $0.01 \mathrm{~mol}$.) of meta toludine in $5 \mathrm{ml}$ of THF. And stirred at r.t for $1 \mathrm{hr}$. at $60-65^{\circ} \mathrm{C}$, after that $4.22 \mathrm{~g}$. of $75 \%$ solution of compound $\mathrm{E}_{2}$ in THF was added gradually within $2 \mathrm{hr}$. while the mixture was then stirring. after complete addition $10 \mathrm{ml}$ of THF was then added and the stirring was continued for further $2 \mathrm{hr}$. at the same temperature after that the solvent was evaporated and to the residue was added $1.98 \mathrm{~g}$ of $30 \%$ methanolic sodium methoxide within a period of 1 hr. stirring was continued for further $3 \mathrm{hr}$. evaporation of methanol gave an oil product $57 \%$ which was used in next step.

\section{Synthesis of 2-Amino thiazole -5- (3-methyl phenyl) Carboxy Amide $\left(\mathrm{E}_{4}\right)$}

Compound $\mathrm{E}_{3}$ (1.5 g, ,0048 mol.), $3.5 \mathrm{ml}$ of acetic acid and 1.09 g. of HCL were mixed together and stirred at $60-65^{\circ} \mathrm{C}$, then $0.92 \mathrm{~g}$. of thiouria was added, the stirring was continued for $11 \mathrm{hr}$. at the same temperature. The reaction was subject for distillation to distill the excess acetic acid methanol $8.47 \mathrm{ml}$ was then added together with $1.35 \mathrm{~g}$. of $30 \%$ methanolic sodium methoxide until $\mathrm{pH}$ of the mixture becomes 8-9. The reaction mixture was filtered off, to the filtrate was added $2 \mathrm{~g}$. of activated charcoal and stirred at $60 \stackrel{\circ}{\circ}$ for $1 \mathrm{hr}$., filtered evaporation of the solvent, $20 \mathrm{ml}$ of cold water was then added to the residue. The final mixture was cooled to $0^{\circ} \mathrm{C}$. the yellow oil was extracted with ether, the extract was evaporated to give oil product $55 \%$.

\section{Synthesis of Some Furyl Substituents of polyhydroquin- oline $\left(E_{5-7}\right)$}

A mixture of (0.96 g., $0.01 \mathrm{~mol}$.) of furfural, (1.4, $0.01 \mathrm{~mol}$.) of dimedon, ( $0.015 \mathrm{~mol}$.) of ammonium carbonate and ( $0.013 \mathrm{~mol}$.) of either methyl acetoacetate or ethyl acetoacetate or acetyl acetone in $30 \mathrm{ml}$ of water. The final mixture was sonicated at $60^{\circ} \mathrm{C}$ for $1 \mathrm{hr}$. After complete reaction (TCL) the reaction was cooled and filtered, washed with water and with $25 \mathrm{ml}$ of $50 \%$ Ethanol. The p.pt was recrystallized from ethanol. physical data were presented in Table 1.

Table 1: Physical data of compounds $\left(E_{5-7}\right)$.

\begin{tabular}{|c|c|c|c|c|c|}
\hline Comp. No. & R & m.p. ( ${ }^{\circ} \mathbf{C}$ ) & $\begin{array}{c}\text { Molecular } \\
\text { Formula }\end{array}$ & Yield (\%) & Color \\
\hline E5 & $-\mathrm{OCH}_{3}$ & $178-180$ & $\mathrm{C}_{18} \mathrm{H}_{21} \mathrm{NO}_{4}$ & 88 & Yello \\
\hline E6 & $-\mathrm{OCH}_{2} \mathrm{CH}_{3}$ & $167-169$ & $\mathrm{C}_{19} \mathrm{H}_{23} \mathrm{NO}_{4}$ & 90 & Yello \\
\hline E7 & $-\mathrm{CH}_{3}$ & $207-208$ & $\mathrm{C}_{18} \mathrm{H}_{21} \mathrm{NO}_{3}$ & 75 & Brown \\
\hline
\end{tabular}

Synthesis of Some Furyl Substituents of 3,4 dihydroprymidine -2-one $\left(\mathrm{E}_{8-14}\right)$

Urea or thiouria and dibromo furfural (0.015 mol.) were mixed together. To the mixture was added methyl or ethyl acetoacetate or acetyl acetone or benzoyl acetone, $50 \mathrm{ml}$ of ethanol and $0.08 \mathrm{~mol}$. Of sulfuric acid. The final mixture was irradiated with ultrasound at $25-30^{\circ} \mathrm{C}$ for $45 \mathrm{~min}$. the reaction was monitored by TLC. After completion of the reaction the mixture was filtered off. The residue was washed with water then with ethanol, dried and recrystallized from 95\% ethanol physical and data are illusterated in Table 2.

Table 2: Physical data of compounds $\left(\mathrm{E}_{8-14}\right)$.

\begin{tabular}{|c|c|c|c|c|c|c|c|}
\hline Comp. No. & $\mathbf{R}$ & $\mathbf{X}$ & $\mathbf{Y}$ & $\mathbf{m . p .}(\mathbf{O C})$ & Molecular Formula & Yield \% & Color \\
\hline $\mathrm{E} 8$ & $-\mathrm{OCH}_{3}$ & 0 & $-\mathrm{Br}$ & $240-242$ & $\mathrm{C}_{11} \mathrm{H}_{10} \mathrm{Br}_{2} \mathrm{~N}_{2} \mathrm{O}_{4}$ & 70 & Brown \\
\hline $\mathrm{E} 9$ & $-\mathrm{OC}_{2} \mathrm{H}_{5}$ & $\mathrm{~S}$ & $-\mathrm{H}$ & $219-221$ & $\mathrm{C}_{12} \mathrm{H}_{14} \mathrm{~N}_{2} \mathrm{O}_{3} \mathrm{~S}$ & 65 & Yellow \\
\hline $\mathrm{E} 10$ & $-\mathrm{OC}_{2} \mathrm{H}_{5}$ & 0 & $-\mathrm{Br}$ & $231-233$ & $\mathrm{C}_{12} \mathrm{H}_{12} \mathrm{Br}_{2} \mathrm{~N}_{2} \mathrm{O}_{4}$ & 64 & Yellow \\
\hline $\mathrm{E} 11$ & $-\mathrm{CH}_{3}$ & 0 & $-\mathrm{H}$ & $218-220$ & $\mathrm{C}_{11} \mathrm{H}_{12} \mathrm{~N}_{2} \mathrm{O}_{3}$ & 48 & Yellow \\
\hline $\mathrm{E} 12$ & $-\mathrm{CH}_{3}$ & 0 & $-\mathrm{Br}$ & $232-234$ & $\mathrm{C}_{11} \mathrm{H}_{10} \mathrm{Br}_{2} \mathrm{~N}_{2} \mathrm{O}_{3}$ & 55 & Yellow \\
\hline $\mathrm{E} 13$ & $-\mathrm{CH}_{3}$ & $\mathrm{~S}$ & $-\mathrm{H}$ & $246-238$ & $\mathrm{C}_{11} \mathrm{H}_{12} \mathrm{~N}_{2} \mathrm{O}_{2} \mathrm{~S}$ & 50 & Yellow \\
\hline $\mathrm{E} 14$ & $-\mathrm{ph}$ & 0 & $-\mathrm{H}$ & $254-256$ & $\mathrm{C}_{16} \mathrm{H}_{14} \mathrm{~N}_{2} \mathrm{O}_{3}$ & 60 & Yellow \\
\hline
\end{tabular}

Synthesis of some furan substituents of amino alkyl naphthol $\left(\mathrm{E}_{15-18}\right)$

Furfural (0.69 g., 0.01 mol.), $0.01 \beta$-naphthol, $0.01 \mathrm{~mol}$. of acetamide or urea or methyl urea and $\left(0.01 \mathrm{~mol}\right.$.) of $\mathrm{ZrOCl}_{2} .8 \mathrm{H}_{2} \mathrm{O}$ in $50 \mathrm{ml}$ of 1,2 - dichloro ethane. The final solution was sonicated at r.t for $40 \mathrm{~min}$. after complete reaction (TLC monitoring), The mixture was filtered off, washed with ether then with water, dried and recrystallized from methanol. physical and spectral data are illustrated in Table 3. The same above procedure was used for synthesizing of compound E20-23 at $60^{\circ} \mathrm{C}$ and sonication for 30 min. The crude product was recrystallized from methanol and the physical properties are shown in Table 4.

Table 3: Physical data of compounds $\left(\mathrm{E}_{15-18}\right)$.

\begin{tabular}{|c|c|c|c|c|c|}
\hline Comp. No. & R & m.p. ( $\left.{ }^{\circ} \mathbf{C}\right)$ & $\begin{array}{c}\text { Molecular } \\
\text { Formula }\end{array}$ & Yield (\%) & Color \\
\hline E15 & $-\mathrm{CH}_{3}$ & $216-217$ & $\mathrm{C}_{17} \mathrm{H}_{15} \mathrm{NO}_{3}$ & 62 & Brown \\
\hline E16 & $-\mathrm{NH}_{2}$ & $220-222$ & $\mathrm{C}_{16} \mathrm{H}_{14} \mathrm{~N}_{2} \mathrm{O}_{3}$ & 65 & Brown \\
\hline E17 & $-\mathrm{NHCH}_{3}$ & $178-180$ & $\mathrm{C}_{17} \mathrm{H}_{16} \mathrm{~N}_{2} \mathrm{O}_{3}$ & 60 & Brown \\
\hline E18 & $-\mathrm{NHCH}_{2} \mathrm{CH}_{3}$ & $205-207$ & $\mathrm{C}_{18} \mathrm{H}_{18} \mathrm{~N}_{2} \mathrm{O}_{3}$ & 62 & Brown \\
\hline
\end{tabular}


Table 4: Physical data of compounds $\left(\mathrm{E}_{19-22}\right)$.

\begin{tabular}{|c|c|c|c|c|c|}
\hline Comp. No. & $\mathbf{R}$ & m.p. $\left.{ }^{\circ} \mathbf{C}\right)$ & $\begin{array}{c}\text { Molecular } \\
\text { Formula }\end{array}$ & $\begin{array}{c}\text { Yield } \\
\text { (\%) }\end{array}$ & Color \\
\hline E19 & $-\mathrm{CH}$ & $219-220$ & $\mathrm{C}_{17} \mathrm{H}_{15} \mathrm{NO}_{3}$ & 62 & Brown \\
\hline E20 & $-\mathrm{NH}_{2}$ & $250-252$ & $\mathrm{C}_{16} \mathrm{H}_{14} \mathrm{~N}_{2} \mathrm{O}_{3}$ & 66 & Brown \\
\hline E21 & $-\mathrm{NHCH}_{3}$ & $190-192$ & $\mathrm{C}_{17} \mathrm{H}_{16} \mathrm{~N}_{2} \mathrm{O}_{3}$ & 64 & Brown \\
\hline E22 & $-\mathrm{NHCH}_{2} \mathrm{CH}_{3}$ & $161-163$ & $\mathrm{C}_{18} \mathrm{H}_{18} \mathrm{~N}_{2} \mathrm{O}_{3}$ & 57 & Brown \\
\hline
\end{tabular}

\section{Result and Discussion}

\section{Synthesis of 2-aminothiazole -5-(3-methyl phenyl) carboxy amide $\left(\mathrm{E}_{4}\right)$}

The first step of this route was the preparation of 2,3-dibromo acrylic acid from the reaction of Mucobromic acid with sodium hydroxide as shown in Scheme 1, the synthesized compound $\mathrm{E}_{1}$ was characterized by the following IR $\mathrm{cm}^{-1} 3344$ for $\mathrm{OH}$, stretching band at 1765 for $\mathrm{C}=0$ while $\mathrm{C}=\mathrm{C}$ appeared at 1624 ,C-0 at 1394 ,C$\mathrm{Br}$ at 850 .This compound was allowed to react with $\mathrm{SOCl}_{2}$ forming compound $\mathrm{E}_{2}$ which is characterized by the following IR bands $\mathrm{cm}^{-1}: \mathrm{C}=0$ at $1786, \mathrm{C}=\mathrm{C}$ at $1659, \mathrm{C}-\mathrm{Br}$ at 850 and disappearance of the $\mathrm{OH}$ band. Compound $\mathrm{E}_{2}$ was allowed to react with meto toludine forming 2,3-dibromo-N-meta tolyl acryl amide which intern reacts with sodium methoxide result into the formation of $\mathrm{E}_{3}$. This compound was characterized by the following IR $\mathrm{cm}^{-1} 3378$ for $\mathrm{NH}, 1677$ for $\mathrm{C}=\mathrm{O}$, Aromatic $\mathrm{C}=\mathrm{C}$ absorbed between 1457-1605 while C-O appeared at $1312, \mathrm{C}-\mathrm{Br}$ at 832 . The final steps of this route include the reaction of $\mathrm{E}_{3}$ with thiouria forming $\mathrm{E}_{4}$ which is characterized by the following IR stretching bands $\mathrm{cm}^{-1}: 3355$ for $\mathrm{NH}, 1668$ for $\mathrm{C}=\mathrm{O}, 1590$ for $\mathrm{C}=\mathrm{N}, \mathrm{C}=\mathrm{C}$ Aromatic appeared within 1445-1612, C-S sym. and asym. At 766, 1093 respectively. The amide group test showed positive result.

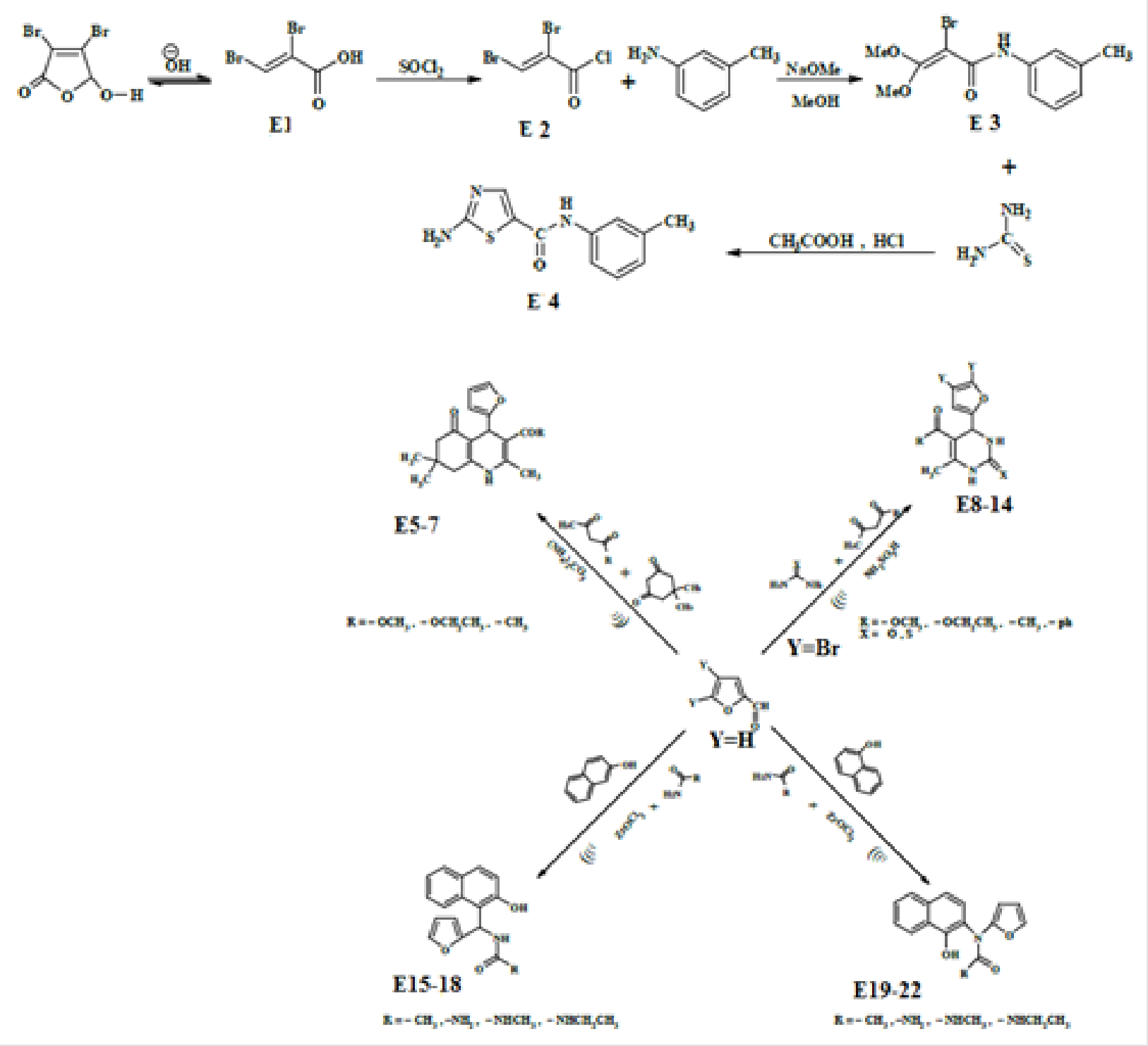

Scheme 1. 
Synthesis of Some Furyl Substituent of Poly Hydro Quinolone ( $\left.\mathrm{E}_{5-7}\right)$

The reaction of furfural, dimedon and one of (methyl, Ethyl acetoacetate, acetyl acetone) in water afforded the title compounds.

Table 5: IR spectral data of compounds $\left(\mathrm{E}_{5-7}\right)$.
These compounds were characterized by IR as shown in Table 5 in which $\mathrm{NH}$ appeared between $3286-3348 \mathrm{~cm}^{-1}, \mathrm{C}=0$ at $1656-1666$ $\mathrm{cm}^{-1}, \mathrm{C}=\mathrm{C}$ Ar. Appeared at $1605-1626 \mathrm{~cm}^{-1}, \mathrm{C}-0$ stretching both sym. and asym. At 1095-1238 $\mathrm{cm}^{-1}$. This finding was in agreement with previously published similar compounds [22].

\begin{tabular}{|c|c|c|c|c|c|c|}
\hline Comp. No. & $\mathbf{R}$ & \multicolumn{5}{|c|}{ IR V(cm-1), 1219, $\mathbf{K B r}$} \\
\hline & & NH & C=0cy & C=C & C-C-Cassym,Sym & Other \\
\hline E5 & $-\mathrm{OCH}_{3}$ & 3286 & 1666 & 1605 & 1219,1143 & $1710(\mathrm{C}=0)$ \\
\hline E6 & $-\mathrm{OC}_{2} \mathrm{H}_{5}$ & 3313 & 1664 & 1626 & 1238,1095 & $1697(\mathrm{C}=0)$ \\
\hline E7 & $-\mathrm{CH}_{3}$ & 3346 & 1655 & 1608 & 1219,1147 & $1676(\mathrm{C}=0)$ \\
\hline
\end{tabular}

Synthesis of Some Furyl Substituent of 3,4 -dihydro pyrimidine 2-one, 2-thio $\left(\mathrm{E}_{8-14}\right)$

This series of compounds were prepared by ultrasonic irradiation of 4,5-dibromo furfural with uria or thiouria and one of compounds (Methyl, Ethyl acetoacetate, acetyl acetone and benzoyl acetone) see Scheme 1. The synthesized compounds were characterized by the following absorption bands $\mathrm{cm}^{-1}: 3248-5317$ for $\mathrm{NH}$ stretching, $1624-1712$ for $\mathrm{C}=\mathrm{O}, \mathrm{C}=\mathrm{C}$ Aromatic appeared at 1450-1647 while C-N absorbed at $1145-12140$ see Table 6. Compound 9 as representative of the series was characterized by Table 6: IR spectral data of compounds $\left(\mathrm{E}_{8-14}\right)$.

\begin{tabular}{|c|c|c|c|c|c|c|c|c|}
\hline \multirow[t]{2}{*}{ Comp. No. } & \multirow[t]{2}{*}{$\mathbf{R}$} & \multirow[t]{2}{*}{$\mathbf{X}$} & \multirow[t]{2}{*}{$\mathbf{Y}$} & \multicolumn{5}{|c|}{ IR V $\left(\mathrm{cm}^{-1}\right), \mathrm{KBr}$} \\
\hline & & & & NH & $\mathrm{C}=0$ & $\mathrm{C}=\mathrm{X}$ & $\mathrm{C}=\mathrm{C}$ & C-N \\
\hline E8 & $-\mathrm{OCH}_{3}$ & 0 & $-\mathrm{Br}$ & 3290 & 1624 & 1608 & 1450 & 1175 \\
\hline E9 & $-\mathrm{OC}_{2} \mathrm{H}_{5}$ & $\mathrm{~S}$ & $-\mathrm{H}$ & 3315 & 1661 & 1191 & 1575 & 1235 \\
\hline E10 & $-\mathrm{OC}_{2} \mathrm{H}_{5}$ & 0 & $-\mathrm{Br}$ & 3232 & 1712 & 1655 & 1512 & 1228 \\
\hline E11 & $-\mathrm{CH}_{3}$ & 0 & $-\mathrm{H}$ & 3317 & 1708 & 1676 & 1647 & 1240 \\
\hline E12 & $-\mathrm{CH}_{3}$ & 0 & $-\mathrm{Br}$ & 3307 & 1698 & 1634 & 1578 & 1223 \\
\hline E13 & $-\mathrm{CH}_{3}$ & $\mathrm{~S}$ & $-\mathrm{H}$ & 3288 & 1630 & 1176 & 1573 & 1145 \\
\hline E14 & $-\mathrm{Ph}$ & 0 & $-\mathrm{H}$ & 3248 & 1645 & 1608 & 1572 & 1213 \\
\hline
\end{tabular}

\section{Synthesis of Furyl Substituent for Naphthol Compounds}

( $\left.\mathbf{E}_{15-19}\right)$

This series of compounds were prepared by irradiation of a mixture of $\beta$ - Naphthol and one of compounds (Acet amide, urea or methyl urea and ethyl urea) in presence of Zarconyl chloride using

Table 7: IR spectral data for compounds $\left(\mathrm{E}_{15-18}\right)$. the following resonating signals in ppm. singlet signal at $10.38 \mathrm{ppm}$., $9.62 \mathrm{ppm}$. for $\mathrm{NH}$ protons, doublet signal at $7.58 \mathrm{ppm}$. for proton at 5 position of furan ring equivalent to $1 \mathrm{H}$, Triplet signal at $6.15 \mathrm{ppm}$. for proton at 3 position of the furan ring equivalent to $1 \mathrm{H}$. Doublet signal at $5.24 \mathrm{ppm}$. for pyridine ring equivalent to $1 \mathrm{H}$, quartet signal of $4.07 \mathrm{ppm}$. belongs to $\mathrm{CH}_{2}$ equivalent $2 \mathrm{H}$, singlet signal at $3.43 \mathrm{ppm}$. belongs to $\mathrm{SH}$ equivalent to $1 \mathrm{H}$, Singlet signal at $2.33 \mathrm{ppm}$. belongs to $\mathrm{CH}_{3}$ proton of Ethyl Ester substituent of pyridine ring equivalent to $3 \mathrm{H}$ triplet signal at substituent 1.12 for $\mathrm{CH}_{3}$ of ester moiety equivelent. to $3 \mathrm{H}$.

\begin{tabular}{|c|c|c|c|c|c|c|}
\hline Comp. No. & $\mathbf{R}$ & \multicolumn{5}{|c|}{ IR V(cm-1), KBr } \\
\hline & & OH & NH & C=0 & C=C C C & C-0-CAssym, Sym \\
\hline E15 & ${ }_{2} \mathrm{CH}-$ & 3441 & 3397 & 1735 & $1436-1647$ & 1020,1220 \\
\hline E16 & ${ }_{2} \mathrm{NH}-$ & 3462 & 3369 & 1747 & $1463-1631$ & 1020,1279 \\
\hline E17 & $\mathrm{NH}_{3} \mathrm{CH}-$ & 3435 & 3336 & 1735 & $1463-1632$ & 1076,1261 \\
\hline E18 & $\mathrm{NHC}_{2} \mathrm{H}_{5}-$ & 3446 & 3317 & 1708 & $1433-1676$ & 1089,1240 \\
\hline
\end{tabular}




\section{Furyl Substituent of $\alpha$-Naphthol Compounds $\left(E_{19-22}\right)$}

The synthesized compounds of this series were also characterized by the following absorption bands IR $\mathrm{cm}^{-1}: 3402$ -

Table 8: IR spectral data for compounds $\left(\mathrm{E}_{19-22}\right)$.
3485 for $\mathrm{OH}$ stretching , 3234-3356 for $\mathrm{NH}$, the carbonyl group was absorbed at 1698-1739 while the aromatic $\mathrm{C}=\mathrm{C}$ appeared within the range (1458-1670) and finally C-O-C for both sym. and asym at 1009-1244 respectively as illustrated in Table 8.

\begin{tabular}{|c|c|c|c|c|c|c|}
\hline Comp. No. & $\mathbf{R}$ & \multicolumn{5}{|c|}{ IR V(cm-1), KBr } \\
\hline & & $\mathbf{O H}$ & $\mathbf{N H}$ & $\mathbf{C = 0}$ & $\mathbf{C}=\mathbf{C}, \mathbf{C} \mathbf{C}$ & C-0-CAssym, Sym \\
\hline $\mathrm{E} 19$ & $-\mathrm{CH}_{3}$ & 3465 & 3356 & 1698 & $1670-1481$ & 1138,1045 \\
\hline $\mathrm{E} 20$ & $-\mathrm{NH}_{2}$ & 3402 & 3249 & 1703 & $1635-1458$ & 1198,1009 \\
\hline $\mathrm{E} 21$ & $-\mathrm{NHCH}_{3}$ & 3433 & 3300 & 1739 & $1655-1508$ & 1244,1022 \\
\hline $\mathrm{E} 22$ & $-\mathrm{NHC}_{2} \mathrm{H}_{5}$ & 3485 & 3234 & 1701 & $1612-1473$ & 1142,1080 \\
\hline
\end{tabular}

\section{Acknowledgement}

Author would like to thank the Iraqi Ministry of higher Education and Research for providing I.M. Shaban a scholarship to do a PhD. In Organic chemistry in which this work is part of this degree project.

\section{Conclusion}

We have demonstrated a simple and green method for efficient synthesis of some heterocyclic compounds containing furyl derivatives within short reaction time and a moderate yield.

\section{References}

1. Chemical Land21, Cyclic aldehyde (Furfural).

2. Sashikala, Ong HK (2007) Synthesis and identification of furfural from rice straw. J Trop Agric 35(1) 165-172.

3. Ambalkar VU, Talib MI (2012) Synthesis of furfural from lignocellulose biomass as agricultural residues. Inter J Eng sci 1(1): 30-36.

4. Punsuvon V, Vaithanomsat P, Liyama K (2008) Simultaneous production of $\alpha$-cellulose and furfural from bagasse by steam explosion pretreatment. Mj Int J Sci Tech 2(1): 182-191.

5. Jong WD, Marcotullio G (2010) Overview of bio refineries based on Coproduction of furfural, Existing concepts and novel developments. Inter J Chem Reactor Eng 8: 3-5.

6. Wankasi D, Naidoo EB (2010) Furfural production from the epicrap of wild mango (irvingia species) fruits by acid catalyzed hydrolysis. Am J Food Nutr 2(2): 47-50.

7. Gebre H, Fisha K, Kindeyaand T (2016) Gebremichalsynthesis of furfural from bagasse. Inter Letter Chem 5 (7): 73-84.

8. Beattie S, Heibron IM, Iraving F (1932) Dicarbocyanines. A new series of cyanine dyes. J Chem Soc 260-268.

9. Gol'dfarb YL, Tarasova LD (1965) Bromination products of furfural. Russian Chem Bulletin 14(6): 1041-1042.

10. Aly AA, Brown AB, El-Emary TI, Ewas AM M, Ramada M (2009) Hyrazinecarbothioamide group in the synthesis of heterocycles. Arkat USA Inc pp. 173.
11. Zare A, Hasaninejad A, Rostam E, Moosavi AR Z, Merajoddin M (2010) PEG-SO3H as a new, highly efficient and homo geneous polymeric catalyst for the synthesis of acylals from aldehydes and acetic anhydride. Scientia Iranica 17(1): 24-30.

12. Forsido BT (2011) Synthesis of 3-methyl-TpMo(CO) 2(5-oxPyranyl) Organometallic scaffold and its application in forming quaternary center at aring junction via an oxidative annulation-demetalation cascade. M.Sc. Thesis, Emory University.

13. Baumann M, Baxendale IR, Ley SV, Nikbin N (2011) An overview of the key routes to the best selling 5- membered ring heterocyclic pharmaceuticals. Beilstein J Org Chem 7: 442-495.

14. Mandalika AS (2012) "Enabling the development of furan-based biorefineries. M.Sc. Thesis, University of Wisconsin-Madison.

15. Martins P, Jesus J, Santos S, Raposo LR, Roma-Rodrigues C (2015) Heterocyclic Anticancer Compounds: Recent Advances and the Paradigm Shift towards the Use of Nanomedicine's Toolbox. Molecules 20(9): 16852-16891.

16. Bruno I, DeSimone R (2010) Design, Synthesis and pharma-cological studies of structural analogues modeled on bioactive natural products. PhD., Thesis, University of Salerno.

17. Al-Ajely MS, Shaban IM (2018) Synthesis of Some Heterocyclic Compounds Derived from Furfural. J Addict Resea 1: 1-6.

18. Al-Ajely MS, Shaman IM (2019) Synthesis of some Pipridine, Pyrmidine and Diazipine compounds contining furyl derivatives. Arch Nanomed 1(5): 133-37.

19. Al-Ajelt MS, Shaban IM (2019) Synthesis of some diazine and triaazole derivatives from furfural. Int J resea 7(4): 83-89.

20. Myer B (2006) preparation of 2-amino thiazole5-carboxylic acid derivitives, US patent, international application No.PCT/ US2006/030198,international publication No.WO2007/019210A1.

21. Bellina F, Rossi R (2007) An efficient and inexpensive multigram synthesis of 3, 4-dibromo-and 3, 4-dichlorofuran-2 (5H)-one. Synthesis 12: 1887-1889.

22. Tanna JA, Chaudhary RG, Sonkusare VN, Juneja HD (2016) CuO nanoparticles: synthesis, characterization and reusable catalyst for polyhydroquinoline derivatives under ultrasonication. J Chine Advan Mater Socie 4(2): 110-122. 
ISSN: 2574-1241

DOI: 10.26717/BJSTR.2019.22.003684

Mohammad S Al-Ajely. Biomed J Sci \& Tech Res

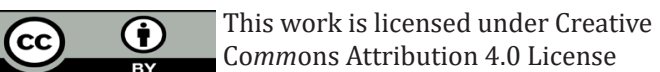

Submission Link: https://biomedres.us/submit-manuscript.php

$\begin{array}{ll}\text { BIOMEDICAL } & \text { Assets of Publishing with us } \\ \text { RESEARCHES } & \text { - Global archiving of articles } \\ & \text { - Immediate, unrestricted online access } \\ & \text { - Rigorous Peer Review Process } \\ \end{array}$

